\title{
Antibiotic Sensitivity and Virulence Genes in Staphylococcus aureus Isolates from Surgical Site Infection
}

\author{
Marufa Zerin Akhter ${ }^{* 1}$, Nuheen Akter ${ }^{2}$, Sunjukta Ahsan ${ }^{1}$, Fatema Moni Chowdhury ${ }^{2}$ \\ ${ }^{I}$ Department of Microbiology, University of Dhaka; ${ }^{2}$ Department of Microbiology, Jagannath University
}

\begin{abstract}
Fourteen multi drug resistant Staphylococcus aureus isolates from surgical site infection were analyzed for their antibiotic sensitivity and the presence of nine virulence genes. The isolates showed a high resistance pattern, all being resistant to methicillin, oxacillin, azithromycin, ceftazidime and amoxyclav. Seven of the isolates were sensitive to linezolid; three were sensitive to trimethoprim: sulfamethoxazol and another three were sensitive to ciprofloxacin. Ceftriaxone, gentamicin and amikacin were the drugs of choice as nine $(64.3 \%)$ isolates were sensitive to ceftriaxone, eleven (78.6\%) were sensitive to gentamicin and another eleven (78.6\%) to amikacin. The present study focused to identify nine important virulence genes including intrinsic methicillin resistance gene mec $A$, methicillin resistance assisting gene $f e m A$, toxic shock syndrome toxin gene $t$ st, exfoliative toxin $\mathrm{A}$ and B genes, eta and $e t b$, Panton Valentine leukocidin gene $L u k S / F-P V L$, along with three enterotoxin genes sec, sed and see. According to the presence of mecA gene and antibiotic resistance profile, two isolates were identified as methicillin resistant Staphylococcus aureus. However, another isolate, despite harbouring both $m e c A$ and $f e m A$ genes, was sensitive to ceftriaxone which excluded it from being considered as an MRSA. Thus, the ratio of MRSA can be considered to be quite high (2/14) among the strains. Interestingly, most of the isolates (10/14) harboured $f e m A$ gene, the majority of which were $m e c A$ negative with an MSSA type antibiotic profile. Although considered as a marker for community acquired MRSA, LukS/F-PV was found in half of these nosocomial isolates. Five, four and two of the isolates harboured etb, tst and sec gene, respectively. However, all the isolates were negative for eta, sed and see genes. Two isolates showed the co-existance of "fem A, LukS/F-PV, etb, and tst" genes. Another two virulence gene patterns observed were "fem A, mec A, tst, sec" and "fem $A, L u k S / F-P V$, etb". The presence of several virulence genes can be correlated to the highly pathogenic nature of the isolates.
\end{abstract}

Key words: Virulence gene, surgical site infection, Staphylococcus aureus, MRSA.

\section{Introduction}

In every surgical procedure, there is a chance of developing surgical site infection. During incision through patient's skin, the chance of microbial skin flora getting entry inside the wound remains there no matter how sincerely aseptic procedures are followed. The CDC healthcare-associated infection (HAI) prevalence survey found that in 2015 there were an estimated 110,800 surgical site infections (SSIs) associated with inpatient surgeries in the United States Hospitals ${ }^{1}$. However, wiping of the incision site with properly diluted antiseptic solution for adequate amount of contact time described by the manufacturer decreases the rate of surgical site infections. Nevertheless, such wounds can be infected through the persons involved in the surgery processes ${ }^{2}$. Of all the reported cases of inpatient nosocomial infections, SSI has secured the third position according to The National Nosocomial Infections Surveillance (NNIS) system set by the Centers for Disease Control (CDC). According to a study carried out by Lee et al. (2006), SSIs accounted for up to $16 \%$ of nosocomial infections in all hospitalized patients and $38 \%$ of all surgical patients ${ }^{3}$. Infection by Methicillin-resistant Staphylococcus aureus (MRSA) can occur at surgical sites with an incidence that varies from $1 \%$ to $33 \%$ depending upon the type of surgery performed ${ }^{4,5}$. There are not many studies conducted on what treatment regimen can be followed to treat Staphylococci infections at surgical sites; however, Linezolid and Vancomycin have been found to be effective ${ }^{4,5}$. There is no conclusive reported information available in Bangladesh as to the percentage of SSI incidents each year and the types of surgical wound involved in every case. However, generally, there are information of such infections that predisposes heavy burden of morbidity with subsequent financial expenses ${ }^{6}$. The present study carried out a research on the presence and comparative prevalence of a few important virulence genes and drug resistance patterns of Staphylococcus aureus isolates from surgical site infections and tried to correlate these two results. The samples collected were from adult inpatients of a reputed hospital of Bangladesh.

\section{Materials and Methods}

Sample collection

The samples of surgical site infections were collected aseptically by swab method or by collecting surgical wound discharges. 
These samples were collected from surgery and gynaecology wards of a reputed hospital of Bangladesh. Isolated bacterial colonies were obtained from the hospital. One presumptively identified discrete colony was inoculated in $1 \mathrm{~mL}$ Tryptic Soy broth (TSB) and the tubes were tightly sealed with parafilm, transported to the laboratory and preserved at $4^{\circ} \mathrm{C}$ refrigerator until further investigation.

Presumptive Identification by Cultural, Morphological and Biochemical Methods

Colony characteristics were observed on Mannitol Salt Agar. Cell shape and arrangements were observed under the microscope. Catalase, oxidase, citrate, Kligler's Iron Agar, glucose, lactose and mannitol fermentation, motility, urease, indole, nitrate reduction, methyl red and Voges Proskauer tests were carried out following the procedures described in Bergey's Manual of Determinative Bacteriology.

\section{Antibiotic Sensitivity Test}

Bacterial susceptibility to antimicrobial agents was determined by disk diffusion method as recommended by Clinical and Laboratory Standards Institute (CLSI, 2018) using commercially available antibiotic discs ${ }^{7}$.

\section{Preparation of template DNA for PCR}

A single colony from LB agar was mixed with $20 \mu \mathrm{L}$ milli-Q water. The mixture was heated at $100^{\circ} \mathrm{C}$ for 10 minutes on a PCR block (MJ Research, USA). Heat lysed cells were centrifuged for 5 minutes in a short spin machine (ABC-M6 mini centrifuge, USA). Cell debris were pelleted at the bottom and the supernatant containing DNA was used as the template DNA for subsequent PCR reactions ${ }^{8}$.

\section{PCR primers}

Primers used in PCR reactions are detailed in Table 1.

\section{PCR master mix}

Commercial master mix preparation (Maximo Taq DNA Polymerase 2X-preMix, GeneON, Germany) was used in all the PCR reactions. It was two times $(2 \mathrm{x})$ concentrated and contained $0.1 \mathrm{U} / \mathrm{ml}$ Taq DNA polymerase, $0.4 \mathrm{mM}$ each of the four types of dNTPs, $4 \mathrm{mM} \mathrm{MgSO}$, $20 \mathrm{mM} \mathrm{KCl}, 16 \mathrm{mM} \mathrm{NH}_{4} \mathrm{SO}_{4}, 20 \mathrm{mM}$ Tris-HCl with a $\mathrm{pH}$ of 8.8 .

\section{Preparation of reaction mixture}

A final volume of $25 \mathrm{~mL}$ was used for singleplex PCR reaction mixture for mecA, femA and $L u k S / F-P V$ genes. Whereas, a final volume of $50 \mu \mathrm{L}$ was prepared for multiplex PCR for "eta, etb, tst" and "sec, sed and see" genes. PCR mix was prepared following the manufacturer's instruction. $\mathrm{MgCl}_{2}$ was added at a final concentration of $2.0 \mathrm{mM}$ in the reaction mixture to achieve greater efficiency of the Taq DNA polymerase enzyme. Additionally, $0.5 \mu$ l Dimethylsulfoxide (DMSO) was added in every $25 \mathrm{~mL}$ reaction mixture to reduce non-specific annealing of the primers. PCR reactions were carried out in a programmable Gradient cycler (MJ Research, USA) that involved an initial DNA

Table 1. Primers used in the PCR method to amplify the virulence genes of S. aureus.

\begin{tabular}{|c|c|c|c|c|}
\hline Target gene & Primer sequences ( $5^{\prime}$ to $\left.3^{\prime}\right)$ & $\begin{array}{c}\text { Amplicon } \\
\text { size (bp) }\end{array}$ & $\begin{array}{l}\text { Annealing } \\
\text { Temp. }\left({ }^{\circ} \mathrm{C}\right)\end{array}$ & Reference \\
\hline mecA & $\begin{array}{ll}\mathrm{F} & \text { ACTGCTATCCACCCTCAAAC } \\
\mathrm{R} & \text { CTGGTGAAGTTGTAATCTGG }\end{array}$ & 163 & 55 & 9 \\
\hline femA & $\begin{array}{lc}\mathrm{F} & \text { AAAAAAGCACATAACAAGCG } \\
\mathrm{R} & \text { GATAAAGAAGAAACCAGCAG }\end{array}$ & 132 & 50 & 10 \\
\hline$L u k S / F-P V$ & $\begin{array}{ll}\mathrm{F} & \text { ATCATTAGGTAAAATGTCTGGACATGATCCA } \\
\mathrm{R} & \text { GCATCAAGTGTATTGGATAGCAAAAGC }\end{array}$ & 433 & 65 & 11 \\
\hline eta & $\begin{array}{ll}\mathrm{F} & \text { GCAGGTGTTGATTTAGCATT } \\
\mathrm{R} & \text { AGATGTCCCTATTTTTGCTG }\end{array}$ & 93 & 50 & 12 \\
\hline$e t b$ & $\begin{array}{l}\text { F } \\
\mathrm{R}\end{array}$ & 226 & 50 & 13 \\
\hline tst & $\begin{array}{lc}\mathrm{F} & \text { ACCCCTGTTCCCTTATCATC } \\
\mathrm{R} & \text { TTTTCAGTATTTGTAACGCC }\end{array}$ & 326 & 50 & 14 \\
\hline $\mathrm{sec}$ & $\begin{array}{ll}\mathrm{F} & \text { AGATGAAGTAGTTGATGTGTATGG } \\
\mathrm{R} & \text { CACACTTTTAGAATCAACCG }\end{array}$ & 451 & 50 & 15 \\
\hline sed & $\begin{array}{l}\mathrm{F} \text { CCAATAATAGGAGAAAATAAAAG } \\
\mathrm{R} \text { ATTGGTATTTTTTTTCGTTC }\end{array}$ & 278 & 50 & 16 \\
\hline see & 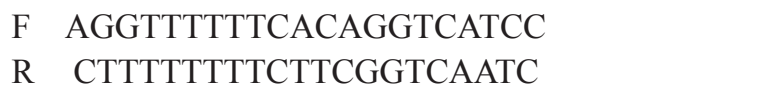 & 209 & 50 & 17 \\
\hline
\end{tabular}


denaturation $\left(95^{\circ} \mathrm{C}\right.$ for 5 minutes), followed by 30 cycles of denaturation $\left(95^{\circ} \mathrm{C}\right.$ for 10 seconds), primer annealing (specified temperature for 10 seconds) and product extension $\left(68^{\circ} \mathrm{C}\right.$ for 1 minute). A final DNA extension step $\left(68^{\circ} \mathrm{C}\right.$ for 7 minutes $)$ completed the reaction. Specific annealing temperature used: mec $A 55^{\circ} \mathrm{C}$; fem $A 50^{\circ} \mathrm{C}$; $L u k S / F-P V 65^{\circ} \mathrm{C}$; for the two separate multiplex PCR reactions $50^{\circ} \mathrm{C}$ temperature was applied.

\section{Resolution of PCR Products by Agarose Gel Electrophoresis}

PCR amplicons were analyzed using agarose gel electrophoresis described by Johansson ${ }^{18}$. Agarose (Sigma) was dissolved by heating in $1 \mathrm{X}$ Tris-borate-EDTA (TBE) buffer to give a final concentration of $1.2 \%$ agarose $(\mathrm{w} / \mathrm{v})$. When the temperature of the dissolved agarose dropped to $50^{\circ} \mathrm{C}, 5 \mu$ l ethidium bromide $(40 \mu \mathrm{g} / \mathrm{ml})$ was added and it was poured onto the gel casting tray (Biometra, Germany). The gel was submerged in 1X TBE buffer in a gel running tank. $10 \mathrm{~mL}$ PCR product was mixed with $2 \mathrm{ml}$ of 6X gel loading dye (Promega, UK, Blue orange dye) and loaded into the wells of the gel with the aid of a micropipette. Electrophoresis was carried out at 70 volts until the tracking dye migrated sufficiently. Then the gel was observed under a UV transilluminator (Gel Doc, Bio-Rad, USA). The 100 bp ladder (Invitrogen, UK) was used as the molecular weight marker.

\section{Results}

A total of 20 isolates from 20 different samples presumptively identified as $S$. aureus from surgical wound infection were collected in this research. Among these, fourteen were found to be Staphylococcus aureus based on their growth on Mannitol Salt Agar (MSA), microscopy and biochemical tests. The isolates showed characteristic yellow colonies on MSA and showed gram positive cocci in grapelike clusters under the microscope. All the biochemical test results were in accordance with the specified biochemical characteristics of $S$. aureus as described in Bergey's Manual of Determinative Bacteriology. The isolates were positive for catalase, glucose, lactose, mannitol, urease, nitrate reduction, Methyl Red and Voges Proskauer tests, while negative for oxidase, citrate, $\mathrm{H}_{2} \mathrm{~S}$ production, motility and indole test.

\section{Antibiotic sensitivity patterns of the isolates}

The antibiotic sensitivity patterns of the fourteen $S$. aureus isolates studied are presented in Table 2. All the isolates showed a high resistant profile being resistant to methicillin, oxacillin, azithromycin, ceftazidime and amoxyclav. Three isolates were sensitive to trimethoprim: sulfamethoxazol and another three to ciprofloxacin. On the other hand, linezolid, ceftriaxone, gentamicin and amikacin were the drugs of choice showing greater sensitivities.

\section{Virulence genes}

It was observed that the highest number of isolates (10 out of 14) contained femA gene. LukS/F-PVL (6 out of 14) and etb (5 out of 14) genes were quite frequent. Three of the isolates possessed mecA gene. Exfoliative toxin eta and enterotoxic sed and see genes were absent in all of the isolates. The relative abundance and distribution of all the genes is represented in figure 2 and table 2. Isolates 8 and 9 showed the presence of $f e m A, L u k S / F$ $P V$, etb, and $t s t$; whereas, isolates 28 and 29 showed the similar gene content each having femA, mecA, tst and sec. On the other hand isolate 38 and 144 had similar virulence gene profiles each containing femA, LukS/F-PV and etb. Figure 1 below shows the agarose gel electrophoresis of the amplified PCR products.

Table 2. Antibiotic sensitivity and virulence gene profile of the S. aureus isolates.

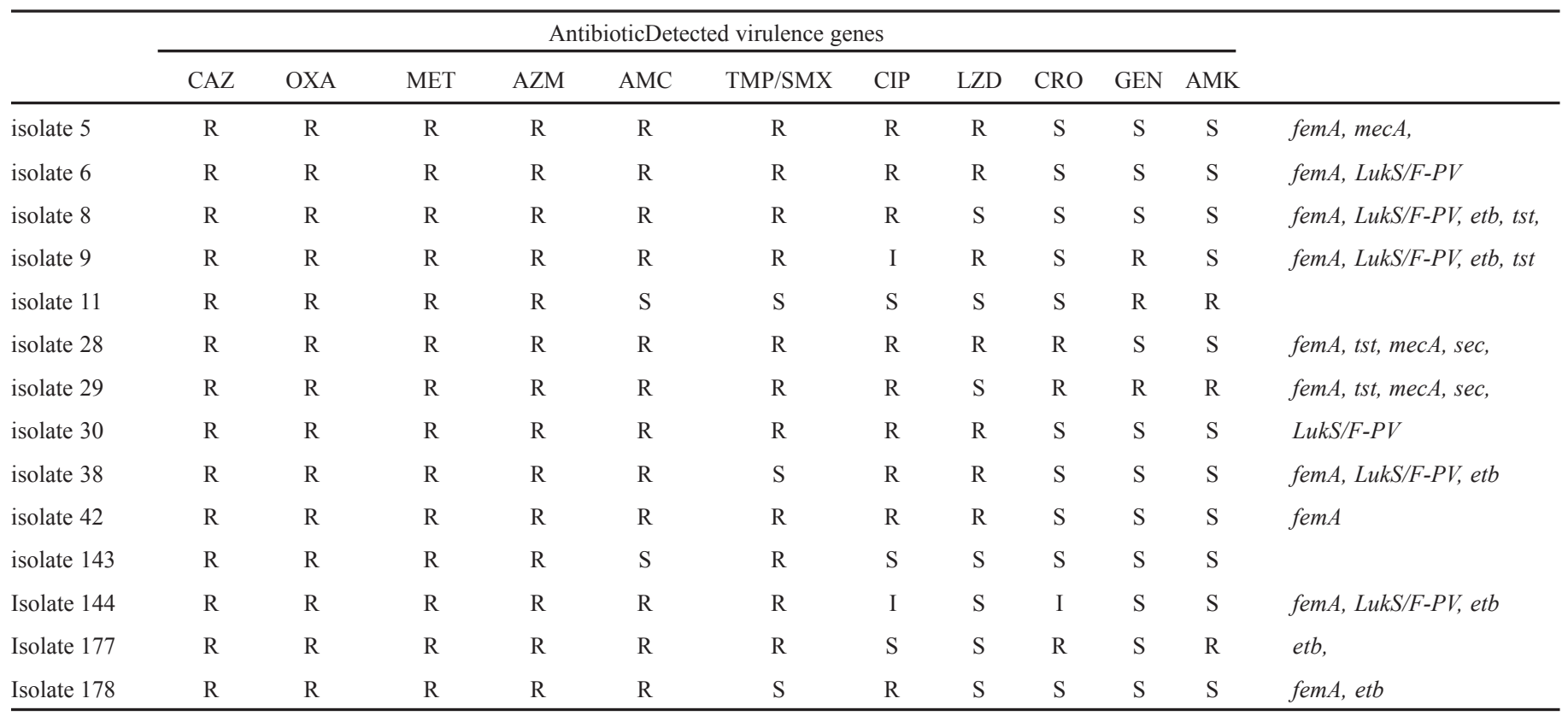

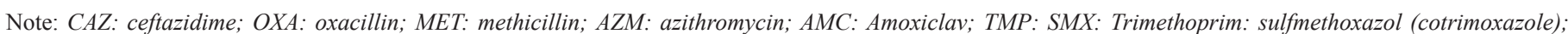
CIP: ciprofloxacin; LZD: linezolid; CRO: ceftriaxone; GEN: gentamicin; AMK: amikacin. 

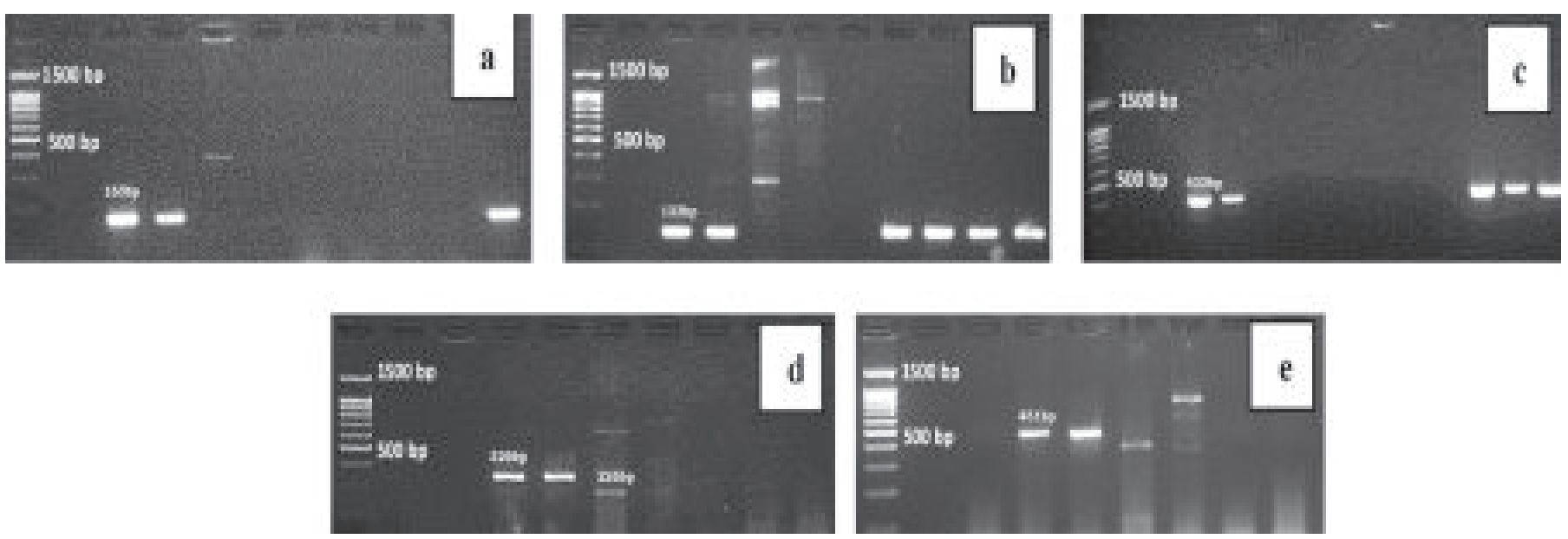

Fig. 1. Agarose gel electrophoresis showing the amplified (a) mecA gene (b) femA gene (c) LukS/F-PV gene (d) multiplex PCR products of eta, etb and tst (e) multiplex PCR products of sec, sed and see. First lane is 100 bp molecular weight marker (Invitrogen, $U K)$.

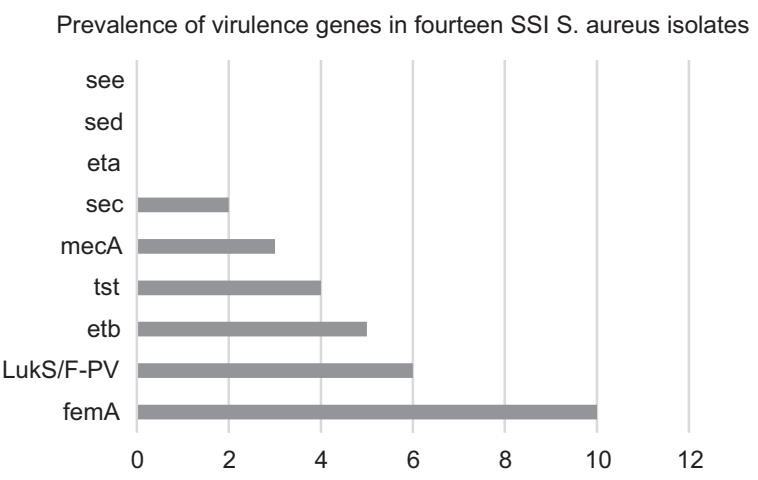

Fig. 2. Prevalence of different virulence genes among the 14 SSI S. aureus isolates.

\section{Discussion}

In general, Gram positive bacteria are considered to be less virulent than Gram negative ones. Staphylococcus aureus can be considered as an exception with its vast array of virulence factors ${ }^{19}$. The emergence of methicillin resistant strains has only made the scenario more complex and emerged as one of the major pathogen involved in public health concern ${ }^{20}$. The different kinds of virulence factors owned by this organism help it to invade, colonize and establish a disease in the host ${ }^{21}$. Many of the virulence factors of $S$. aureus are encoded on plasmids, transposons, prophages and pathogenicity islands ${ }^{22}$. As such, dissemination of these virulence factors among isolates in close proximity in the environment is aggravating the problem of controlling diseases caused by the organism. Staphylococcus aureus can cause a wide range of bacterial infections ranging from minor skin infections to deep seated abscesses and more alarmingly bacteremia that can cause endovascular and metastatic infections leading to a severe condition which makes its treatment extremely complicated. Among the Gram positive bacteria causing bacteremia, $S$. aureus holds the first position ${ }^{23,24}$. It colonizes the skin and anterior nares in about one-third of the healthy population which is a predisposing factor for initiation of infection ${ }^{25}$.

The present study tried to establish a correlation of different virulence genes present with the sensitivity profile which could give us an understanding of the involvement of these genes in disease manifestation and their co-existence in DNA. Also the overall prevalence of these genes in SSI isolates of $S$. aureus was assessed. This study indicated that majority of the isolates irrespective of being MRSA or MSSA, harboured femA gene. This finding makes one curious as to what function femA gene plays in the mecA negative isolates.

S. aureus strains that are oxacillin and methicillin resistant, historically termed methicillin-resistant $S$. aureus (MRSA), are resistant to all B-lactam agents, including cephalosporins and carbapenems, although they may be susceptible to the newest class of MRSA-active cephalosporins (e.g, ceftaroline) ${ }^{26}$. According to this criteria, two of the isolates of the present investigation (isolate 28 and 29) were identified as MRSA. Other isolates resistant to methicillin and oxacillin, were not included in MRSA category, as they were susceptible to some commonly used beta lactams.

As all the isolates were resistant to methicillin and oxacillin, it was expected that all the strains would harbour mecA and $f e m A$ gene. However, the PCR amplification revealed a different scenario; only three of the isolates had mecA gene. Similar findings are available that reported that the disc sensitivity for methicillin resistance do not comply with the presence of the $m e c A$ gene ${ }^{27,28,29,30}$. However, most of the isolates (10 isolates out of 14) harboured femA gene. The remaining oxacillin-resistant isolates (which were $m e c A$ negative) must be methicillin resistant by virtue of some other mechanism ${ }^{31}$. According to various previous reports, methicillin resistance may also be associated with mechanisms independent of $m e c A$, resulting in borderline methicillin resistance. These mechanisms include beta-lactamase 
hyperproduction, production of methicillinases, acquisition of structurally modified normal PBPs, or the appearance of small colony variants of $\mathrm{SA}^{32}$. Aquib et al. (2018) reported a significant discrepancies in mecA dependent methicillin resistance. They reported a significant number of $m e c A$ negative MRSA, as well as $m e c A$ positive $\mathrm{MSSA}^{33}$.

Panton Valentine leukocidin (PVL) is considered one of the important virulence factors of $S$. aureus. It is involved in white blood cell destruction, necrosis, apoptosis and has been used as a marker of community acquired MRSA. A study reported that Panton Valentine leukocidin is present in majority of community associated MRSA isolates and rarely present in hospital isolates, therefore it is recognized as marker of community acquired strains $^{34}$. It is a member of the synergohymenotropic toxin family that induces pores in the membranes of cells. Panton Valentine leukocidin producing MRSA usually causes mild skin or soft tissue infections, however, it also has been associated with necrotizing pneumonia and sepsis ${ }^{35}$. In the present study, LukS/ $F-P V$ gene was found to be present in 6 of the MSSA isolates out of $12(50 \%)$. However, this gene was absent in the two MRSA isolates. Thus this finding correlates to the previous observation of PVL not being present in nosocomial MRSA isolates ${ }^{26}$. However, the high prevalence of this gene in the nosocomial MSSA infection in the present study gives a high virulence potential of these isolates. The point to be noted is that among the six isolates having PVL gene in this study, 5 also had coexistence of femA gene (Table 2).

Microbial superantigen producing sea, seb, sec upto ser genes are involved in the production of staphylococcal enterotoxins A to R sequentially. The enterotoxins are similar to each other in terms of structure and biological activity, but they are antigenically different ${ }^{36}$. The present study also examined the prevalence of such genes namely sec, sed, see and also the toxic shock syndrome tst gene. In the present study, sed and see genes were absent; however, the two suspected MRSA isolates 28 and 29 contained both $t s t$ and $\mathrm{sec}$ genes indicating of their being highly virulent. Presence of such genes can explain the necrotizing ability of the pathogenic $S$. aureus strains studied. Among the two exfoliative toxin gene studied, although eta was absent, etb was quite prevalent among the isolates being present in 5 of the isolates out of 14. However, etb was not present in the two MRSA strains. In a study by Alfatemi et al. (2014) who carried out a similar study reported the frequency of the eta, etb, LukS/F-PV and tst, genes to be $0.68 \%, 2.05 \%, 10.95 \%$ and $11.64 \%$ respectively ${ }^{12}$. Whereas, in the present study the frequency for these genes were $0 \%, 35 \%, 42 \%$ and $28 \%$ respectively. If the sample number in the present study could be increased, the frequency could have been similar.

\section{Conclusion}

The present study was aimed to carry out a research on the virulence gene profiles and drug resistance patterns of multi drug resistant Staphylococcus aureus from clinical samples of
Bangladesh. SSIs are a common phenomenon in the hospitals of Bangladesh in spite of the heavy aseptic precautions taken. Published research on antibiotic resistance profiles of surgical wound infection isolates are scarce in Bangladesh. Although, the drug resistance or drug sensitivity study has started for many years in our country, it has been limited primarily on the antibiotic sensitivity assessment. Previous studies definitely have proved to be beneficial to the health sector of our country. However, very few attempts were made to investigate the presence of specific virulence factor associated genes for any particular species. Isolation and identification of such genes gives us a clear idea as to how these pathogens are actually gaining entry in human body and which genes are frequent and prevalent amongst the isolates and what mechanisms they are using to avert the body's defense mechanisms. Further investigation on the samples are required to gain thorough knowledge of the frequency of other important virulence genes and associated drug resistance and severity of the virulence.

\section{Acknowledgement}

The authors are grateful to the Government of the People's Republic of Bangladesh, Ministry of Education for the grant [Grant of Advanced Research in Education (GARE)]. For providing the samples the authors also acknowledge the support of Dr. Sheikh Shahidul Islam.

\section{References}

1. Magill SS et al. 2018. Changes in Prevalence of Health Care-Associated Infection in U.S. Hospitals. New England Journal of Medicine. 379(18): $1732-44$

2. Florman S and Nicholes RL. 2007. Current approach for the prevention of surgical infections. American Journal of Infectious Diseases. 3: 51-56.

3. Lee J, Singletary R, Schmader K, Anderson DJ, Bolognesi M and Kaye KS. 2006. Surgical site infection in the elderly following orthopaedic surgery. Risk factors and outcomes. J Bone Joint Surg Am. 88: 1705-1712.

4. Foster TJ. 2017. Antibiotic resistance in Staphylococcus aureus. Current status and future prospects. FEMS Microbiology Review. 41(3): 430449. doi: 10.1093/femsre/fux007.

5. Gurusamy KS, Koti R, Toon CD, Wilson P and Davidson BR. 2013. Antibiotic therapy for the treatment of methicillin resistant Staphylococcus aureus (MRSA) infections in surgical wounds. Cochrane Database of Systematic Reviews 2013, Issue 8. Art. No.: CD009726. DOI: 10.1002/ 14651858.CD009726.pub2.

6. Nur-e-elahi M, Jahan I, Siddiqui O, Ahmed SU, Joarder AI, Faruque S, Imdad S, Ahmed HS, Islam MA, Siddiqui MZ and Sardar K. 2011. Wound infection in Surgery Department in BSMMU: A study of 100 cases. Journal of the Bangladesh Society of Anaesthesiologists. 24(2): 65-69.

7. CLSI. 2018. Clinical and Laboratory Standards Institute. Performance standards for antimicrobial susceptibility testing: Twenty-fifth informational supplement M100-S25. CLSI, Wayne, PA, USA.

8. Queipo-Ortuño MI, Colmenero JDD, Macias M, Bravo MJ and Morata P. 2008. Preparation of bacterial DNA template by boiling and effect of immunoglobulin $\mathrm{G}$ as an inhibitor in real-time PCR for serum samples from patients with brucellosis. Clinical and vaccine immunology. 15(2): 293-296. https://doi.org/10.1128/CVI.00270-07 
9. Ryffel C, Tesch W, Birch-Machin I, Reynolds PE, Barberis-Maino L, Kayser FH and Berger-Bachi B. 1990. Sequence comparison of mecA genes isolated from methicillin-resistant Staphylococcus aureus and Staphylococcus epidermidis. Gene. 94(1): 137-138.

10. Berger-Bachi B, Barberis-Maino L, Strassle A and Kayser FH. 1989. FemA, a host-mediated factor essential for methicillin resistance in Staphylococcus aureus: molecular cloning and characterization. Mol. Gen. Genet. 219: 263-269.

11. McClure J, Conly JM, Lau V, Elsayed S, Thomas Louie T, Hutchins W and Zhang K. 2006. Novel Multiplex PCR Assay for Detection of the Staphylococcal Virulence Marker Panton-Valentine Leukocidin Genes and Simultaneous Discrimination of Methicillin-Susceptible from Resistant Staphylococci. Journal of Clinical Microbiology. 44(3): 1141-1144.

12. Alfatemi SMH, Motamedifar M, Hadi N, Saraie SE. 2014. Analysis of Virulence Genes among Methicillin Resistant Staphylococcus aureus (MRSA) Strains. Jundishapur J Microbiol. 7(6): e10741.

13. Jackson MP and Iandolo JJ. 1986. Sequence of the exfoliative toxin B gene of Staphylococcus aureus. J. Bacteriol. 167: 726-728.

14. Blomster-Hautamaa DA, Kreiswirth BN, Kornblum JS, Novick RP and Schlievert PM. 1986. The nucleotide and partial amino acid sequence of toxic shock syndrome toxin-1. J. Biol. Chem. 261: 15783-15786.

15. Bohach GA and Schlievert PM. 1987. Nucleotide sequence of the staphylococcal enterotoxin $\mathrm{C} 1$ gene and relatedness to other pyrogenic toxins. Mol. Gen. Genet. 209: 15-20.

16. Bayles KW and Iandolo JJ. 1989. Genetic and molecular analyses of the gene encoding staphylococcal enterotoxin D. J. Bacteriol. 171: 47994806.

17. Couch JL, Soltis MT and Betley MJ. 1988. Cloning and nucleotide sequence of the type E staphylococcal enterotoxin gene. J. Bacteriol. 170: $2954-2960$

18. Johansson BG. 1972. Agarose gel electrophoresis. Scand. J. Clin. Lab. Invest. 29: 7-21.

19. Cheung GYC, Bae JS and Otto M. 2021. Pathogenicity and virulence of Staphylococcus aureus. Virulence. 12(1): 537-569.

20. Grundmann H, Aires-de-Sousa M, Boyce J and Tiemersma E. 2006. Emergence and resurgence of meticillin-resistant Staphylococcus aureus as a public-health threat. Lancet. 368(9538): 874-85.

21. Voyich JM, Otto M, Mathema B, Braughton KR, Whitney AR, Welty D, Long RD, Dorward DW, Gardner DJ, Lina G, Kreiswirth BN and DeLeo FR. 2006. Is Panton-Valentine leukocidin the major virulence determinant in community-associated methicillin-resistant Staphylococcus aureus disease? J Infect Dis. 194(12): 1761-70.

22. Bose JL, Fey PD and Bayles KW. 2013. Genetic tools to enhance the study of gene function and regulation in Staphylococcus aureus. Appl Environ Microbiol. 79(7): 2218-24.

23. Mathur P, Kapil A and Das B. 2005. Nosocomial bacteraemia in intensive care unit patients of a tertiary care centre. Indian J Med Res. 122: 305-8.

24. Singla N, Bansal N and Chander J. 2011. Staphylococcus aureus bacteremia: A continuing challenge. Ann Trop Med Public Health. 4: $51-2$.
25. Moran GJ, Krishnadasan A, Gorwitz RJ, Fosheim GE, McDougal LK, Carey RB and Talan DA. 2006. Methicillin-resistance S. aureus infections among patients in the emergency department. $N$ Engl J Med. 355: 66674.

26. CDC, Centre for Disease Control and Prevention. 2021. Laboratory Detection of: Oxacillin/Methicillin-resistant Staphylococcus aureus; https://www.cdc.gov/mrsa/lab/index.html. Accessed on $6^{\text {th }}$ June, 2021.

27. Nam LV, Quyet D, Hung PN, Tien TV, Thanh KC, Dung QA, Linh DD, Tan HT, Bac ND, Chu Dinh T and Pho DC. 2019. Antibiotic Resistance Profile and Methicillin-Resistant Encoding Genes of Staphylococcus aureus Strains Isolated from Bloodstream Infection Patients in Northern Vietnam. Open Access Maced J Med Sci [Internet]. 7(24): 4406-10. Available from: https://oamjms.eu/index.php/mjms/article/view

28. Cikman A, Aydin M, Gulhan B, Karakecili F, Kurtoglu MG, Yuksekkaya S, Parlak M, Gultepe BS, Cicek AC, Bilman FB, Ciftci IH, Kara M, Atmaca S, Ozekinci T. 2019. Absence of the mecC gene in methicillin-resistant Staphylococcus aureus isolated from various clinical samples: The first multi-centered study in Turkey. J Infect Public Health. 12(4): 528-533. doi: 10.1016/j.jiph.2019.01.063. Epub 2019 Feb 7. PMID: 30745200.

29. Elhassan MM, Ozbak HA, Hemeg HA, Elmekki MA and Ahmed LM. 2015. Absence of the mecA Gene in Methicillin Resistant Staphylococcus aureus Isolated from Different Clinical Specimens in Shendi City, Sudan. BioMed Research International. vol. 2015, Article ID 895860, 5 pages, 2015. https://doi.org/10.1155/2015/895860

30. Yoshida R, Kuwahara-Arai K, Baba T, Cui L, Richardson JF and Hiramatsu K. 2003. Physiological and molecular analysis of a mecAnegative Staphylococcus aureus clinical strain that expresses heterogeneous methicillin resistance. Journal of Antimicrobial Chemotherapy. 51(2): 247-255. https://doi.org/10.1093/jac/dkg036.

31. Chambers HF. 1997. Methicillin resistance in staphylococci: molecular and biochemical basis and clinical implications. Clin. Microbiol. Rev. 10: 781-791.

32. Brakstad OG and Maeland JA. 1997. Mechanisms of methicillin resistance in staphylococci. Journal of Pathology, Microbiology and Immunology. 105(4): 264-76. DOI: 10.1111/j.1699-0463.1997.tb00568.x

33. Aqib AI, Ijaz M, Farooqi SH, Ahmed R, Shoaib M, Ali MM, Mehmood K and Zhang H. 2018. Emerging discrepancies in conventional and molecular epidemiology of methicillin resistant Staphylococcus aureus isolated from bovine milk. Microb Pathog. 116: 38-43. DOI: 10.1016/ j.micpath.2018.01.005

34. Vandenesch F, Naimi T, Enright MC, Lina G, Nimmo GR, Heffernan H, Liassine N, Bes M, Greenland T, Reverdy ME and Etienne J. 2003. Community acquired methicillin resistant Staphylococcus aureus carrying Panton-Valentine leukocidin genes: worldwide emergence. Emerg Infect Dis. 9: $978-984$.

35. Maltezou HC and Giamarellou H. 2006. Community acquired methicillin resistant Staphylococcus aureus infections. Int J Antimicrob Agents. 27: 87-96.

36. Ertas N, Gonulalan Z, Yildirim Y and Kum E. 2010. Detection of Staphylococcus aureus enterotoxins in sheep cheese and dairy desserts by multiplex PCR technique. Int J Food Microbiol. 142(1-2): 74-7. 